IZA DP No. 10305

Consumption and Leisure: The Welfare Impact of Migration on Family Left Behind

Elie Murard

October 2016 


\title{
Consumption and Leisure: The Welfare Impact of Migration on Family Left Behind
}

\author{
Elie Murard \\ IZA
}

\section{Discussion Paper No. 10305 \\ October 2016}

\author{
IZA \\ P.O. Box 7240 \\ 53072 Bonn \\ Germany \\ Phone: +49-228-3894-0 \\ Fax: +49-228-3894-180 \\ E-mail: iza@iza.org
}

Any opinions expressed here are those of the author(s) and not those of IZA. Research published in this series may include views on policy, but the institute itself takes no institutional policy positions. The IZA research network is committed to the IZA Guiding Principles of Research Integrity.

The Institute for the Study of Labor (IZA) in Bonn is a local and virtual international research center and a place of communication between science, politics and business. IZA is an independent nonprofit organization supported by Deutsche Post Foundation. The center is associated with the University of Bonn and offers a stimulating research environment through its international network, workshops and conferences, data service, project support, research visits and doctoral program. IZA engages in (i) original and internationally competitive research in all fields of labor economics, (ii) development of policy concepts, and (iii) dissemination of research results and concepts to the interested public.

IZA Discussion Papers often represent preliminary work and are circulated to encourage discussion. Citation of such a paper should account for its provisional character. A revised version may be available directly from the author. 


\section{ABSTRACT \\ Consumption and Leisure: The Welfare Impact of Migration on Family Left Behind ${ }^{\star}$}

This paper examines the effect of international migration on the welfare of family members left behind at the origin. Previous literature has produced inconclusive evidence, with some studies suggesting that migration reduces income poverty while others show that nonmigrants bear a larger work burden to compensate for the loss of migrants' earnings. This paper provides a new unified framework that generates testable predictions of whether migration increases non-migrants' welfare in terms of both consumption and leisure time. Drawing on household panel data in rural Mexico, I find that migration increases nonmigrants' consumption, but that this consumption gain cannot be explained by labor supply adjustments. Migration improves left-behinds' welfare through two different channels: (i) migrants' remittances exceed their forgone income contribution to the origin household; and (ii) the out-migration of a farmer increases the marginal productivity of agricultural labor for those left behind in the farm.

JEL Classification: $\quad 015, \mathrm{~J} 22, \mathrm{~F} 22$

Keywords: migration, remittances, welfare, labor supply, consumption, Mexico

Corresponding author:

Elie Murard

IZA

Schaumburg-Lippe-Str. 5-9

53113 Bonn

Germany

E-mail: murard@iza.org

\footnotetext{
* I am grateful to Francois Bourguignon, Marc Gurgand, Hillel Rapoport, Christian Schluter, Christian Dustmann, Denis Cogneau and Sylvie Lambert for their helpful comments.
} 


\section{Introduction}

Does international migration improve the welfare of families left behind at the origin? While migrants may realize important income gains when they move, it is less clear whether those staying behind also benefit. In fact, although non-migrants may benefit from remittance inflows, the local earnings and inputs of the migrants are lost. The literature has traditionally focused on the effects on income or consumption, generally supporting the optimistic view that international migration and remittances reduce poverty among families left behind. Nonetheless, another recent strand of research has produced more mixed conclusions about the effect of migration on non-income dimensions of well-being. ${ }^{1}$ Specifically, a series of studies finds that migration causes members left behind to increase their time spent in farm work and unpaid family work (Binzel and Assaad, 2011; Mu and van de Walle, 2011; Chang et al., 2011; Démurger and Li, 2013; Mendola and Carletto, 2012). Evidence that migration reduces available time out of work has raised the concern of a negative effect on non-migrants' well-being, notably in terms of health and school attendance among children left behind (McKenzie and Rapoport, 2011; Antman, 2010, 2011).

However, these two separate approaches - one in terms of consumption, the other in terms of time allocation - have their own limitations. Given that it ignores the disutility of work, a purely monetary approach focused on consumption may underestimate the welfare losses caused by migration. For example, if the primary breadwinner of the household were to migrate without sending back remittances, this would cause a net income loss for the members left behind. Nonetheless, non-migrants may mitigate this loss and smooth consumption by sufficiently increasing their labor time. No decrease in consumption would then be observed ex-post despite an income loss ex-ante. Thus, a consistent welfare analysis must take into account the leisure costs of the extra income generated by the labor-supply adjustments of non-migrants. ${ }^{2}$

Previous studies focusing on non-migrants' time use have usually overlooked the positive effect of migration on the shadow wage of farm work. In a context of decreasing marginal productivity of labor in agricultural production, the out-migration of a farmer is likely to increase the marginal productivity of labor for those left behind in the farm. Given that the opportunity cost of leisure has increased, non-migrants may work more in the farm to consume more. Therefore, the finding that left-behinds increase their labor supply does not necessarily imply that their welfare has declined.

This paper examines whether — in a rural context — migration increases non-migrants'

1. For a review of the literature, see Adams (2011) and Antman (2013).

2. In the opposite case in which migration generates net income gains for non-migrants, a purely monetary approach focused on consumption gains may underestimate the increase in non-migrants' welfare. This is because non-migrants may use the additional income to purchase leisure time, thereby substituting consumption with more leisure. 
welfare in terms of both consumption and leisure time, rather than in one of these dimensions separately. To answer this question, I provide a unified theoretical framework that models migration as the outcome of a joint welfare maximization by the potential migrant and the rest of the family, with migration decisions essentially being driven by income differential between the local family farm and the foreign labor market. The model highlights the combination of an income and a substitution effect. First, migration has a priori an ambiguous effect on the resources available to non-migrants. While non-migrants can benefit from remittances inflows, the earnings and other inputs that the migrant would have produced locally are lost. The model shows that migration only generates net income gains if migrants' remittances exceed their forgone income contribution to the household (migrant's earnings minus individual consumption). Second, the model emphasizes an effect of migration that has generally gone unnoticed in the micro empirical literature, namely the fact the out-migration of a farmer raises the marginal productivity of agricultural labor for those left behind. ${ }^{3}$ This positive impact of emigration increases the welfare of non-migrants, independent of remittances or any compensation on the part of the migrant, as Drapier et al. (2006) have theorized.

Using household panel data in rural Mexico, I estimate that migration to the U.S. increases the food and non-food expenditure of household members staying behind by about $25 \%$. The principal contribution of this paper is to show that these consumption gains are too large to be explained by endogenous adjustments in non-migrants' labor supply. This proves that migration increases non-migrants' welfare once the utility of consumption and the disutility of work are both taken into account. Further, I find direct evidence of a positive income effect and a substitution effect. I find that the amounts of migrants' remittances tend to exceed their forgone income contribution to the origin household, thereby generating net income gains for those left behind. These income gains appear to persist over time, up to five years after migration, leading to a higher accumulation of household durable assets in the form of financial savings and livestock. Finally, I find that migration causes non-migrants to increase their farm labor (in selfemployment), particularly when the migrant worked in the farm before migrating. This lends support for the positive effect of a farmer's out-migration on the productivity of agricultural labor at the origin.

This paper also contributes to the abundant literature on the impact of migration on Mexican households in two different ways. First, it adds to the scarce evidence on the effects of migration on left-behinds' consumption and time use, while most of the previous studies have focused on the effects of remittances, on labor force participation (Cox-Edwards and RodríguezOreggia, 2009; Amuedo-Dorantes and Pozo, 2006), income volatility (Amuedo-Dorantes and

3. Chang et al. (2011) and Lokshin and Glinskayai (2008) mention this effect but do not examine its welfare implications. Some macro studies also find that emigration has positive effects on equilibrium wages in sending countries, especially in Mexico (Mishra, 2007). 
Pozo, 2011) or vulnerability to poverty at (de la Fuente, 2010). ${ }^{4}$ These studies take migration decisions as given and compare outcomes of recipient households with a counterfactual scenario with no (or less) remittances and with an unchanged household size and composition. Nonetheless as Schiff (2008) shows, abstracting from changes in household size generally results in substantially underestimating the impact of migration on income and poverty. For this reason - and because the group of recipient and migrant-sending households do not coincide (migrants do not always remit) - the effects of migration can be very different from those of remittances. ${ }^{5}$

Second, most of studies of migration impacts rely on cross-sectional data and instrument migration decisions using push or pull factors proxied by household circumstances - e.g. village-level networks, distance to potential areas of destination, economic shocks - the exogeneity of which is often questionable. ${ }^{6}$ In this paper, I am able to move beyond these approaches by taking advantage of panel data. The identification exploits variation in migration decisions across households and over time (between two survey rounds) and uses individual fixed effects to control for time-invariant unobserved heterogeneity. To address the concern of confounding factors varying over time - such as local labor demand shocks - I include municipal-year fixed effects to control for unobserved shocks at a very local level, with municipalities being very small space units in rural Mexico, typically comprising fewer than 2,500 inhabitants. In addition, I provide evidence that within a municipality, household-specific shocks do not drive migration decisions and that there are no differential pre-migration time trends. Almost no studies on the impacts of Mexican migration use panel data, with one exception being Antman (2011). Nonetheless, by using a panel dataset covering only one year (the ENEU), the author can only address the very immediate effects of paternal migration on children's schooling and work outcomes. By contrast, I am able to uncover medium- and long-term effects, up to five years after migration.

Finally, this paper relates to the literature seeking to understand how the gains of migration are shared within the family. It has been clearly established that international migration generates massive income gains for the migrants themselves. ${ }^{7}$ Nonetheless, the extent to which

4. Hanson (2007) is the only study that focuses on the effects of emigration. The author explores whether the labor-supply behavior of individuals born in high- and low-migration Mexican states changed differentially between 1990 and 2000. Nonetheless, as the author acknowledged, shocks other than emigration (e.g. NAFTA trade reform or the 1995 crisis) may have differential impacts on high- and low-migration states and thus confound the estimates.

5. A similar argument can be found in Bertoli and Marchetta (2014). The authors find substantially different effects of migration on poverty among stayers in Ecuador depending on whether they focus on migrant-sending or remittance-recipient households.

6. Historical migration rates in the households' state of residence have been extensively used in the US-Mexico migration literature (McKenzie and Rapoport, 2011, 2007; Woodruff and Zenteno, 2007). Nonetheless, historical migration rates may be correlated with current levels of community development in Mexico and thus could directly affect non-migrants' outcomes.

7. Gibson and McKenzie (2012); Clemens (2013); McKenzie et al. (2010) 
household members left behind also benefit remains unclear, in absolute terms and relative to the migrant. A growing body of literature has shown that transnational households are not immune to non-cooperative behaviors due to acute information asymmetries arising between family members separated over long distance. ${ }^{8}$ Findings in Ambler (2015) and Seshan and Zubrickas (2015) notably suggest that migrants may take strategic advantage of these information asymmetries to send a lower amount of remittances. Gibson et al. (2011) shows that despite the considerable income gains that they realize when moving to New Zealand, Tongan migrants do no remit enough to compensate for their forgone local earnings. This causes members left behind to be worse-off in terms of income per capita and wealth. Similarly, Beegle et al. (2011) find important and persistent differences in consumption growth between migrant and non-migrant members of the same households in Tanzania.

In the context of rural Mexico, the results found in this paper suggest that international migration is largely beneficial to the household members staying behind. This finding is in line with the theory of Stark and Bloom (1985), which views migration as a cooperative and mutually-beneficial contract between the migrant and the rest of the family. Owing to the lack of matched data on migrants and their origin households in Mexico, this paper does not compare the welfare of members left behind relative to the welfare of migrants at the destination.

The remainder of this paper proceeds as follows. Section 2 presents a stylized model generating testable predictions of whether migration increases non-migrants' welfare. Section 3 describes the data used to test these predictions. Section 4 reviews the empirical strategy and discusses possible threats to the identification. Section 5 presents the estimation results, before section 6 concludes.

\section{Theoretical model}

In this section, I develop a stylized model to gain insights into how migration decisions should affect the time allocation and consumption of the non-migrant household members. Individual migration is modeled as the outcome of a household strategy to exploit income differential between local activities and the foreign labor market. At the origin, the household derives income from either farm production or off-farm wage-earning jobs. In order to examine the distribution of welfare within the household, I consider households comprising two members with different skills and with different marginal utility of leisure and consumption. My setting thus departs from standard agricultural household models, which generally use a single agent (Taylor and Adelman, 2003) and is close to the model of Sadoulet et al. (1998) with heterogeneous family labor. The latter is used to predict the membership of landed hou-

8. See Chen (2013); De Laat (2014) and Ashraf et al. (2015) for evidence of strategic efforts of migrants to control remittance spending. 
seholds in different labor regimes - sellers of labor, self-sufficient in labor, and employers depending on the marginal productivity of the farm, on off-farm wages as well as wages paid to hire workers in the farm. Building on this framework, my contribution is to model migration as a labor regime in which : (i) the outside wage of one family member is sufficiently high that he leaves the farm to work in off-farm jobs; (ii) the other member remains in the local farm at the origin. I subsequently derive how the non-migrant member adjusts his labor supply and consumption in response to migration triggered by higher outside wages.

\subsection{Framework}

Formally, I assume that the family maximizes a Bergson-Samuelson joint welfare function $\theta U^{2}+(1-\theta) U^{1}$, with $0<\theta<1$ the Pareto weight. For each $i=1,2$, individual utility $U^{i}$ is a concave function of individual consumption $c_{i}$ and leisure $l_{i}$, which are complementary inputs in the utility $\left(U_{c_{i} l_{i}}^{i} \geq 0\right)$. Each family member allocates his time endowment $T_{i}$ between onfarm work $L_{i}^{F}$, off-farm wage work $L_{i}^{O}$ and leisure $l_{i}$. Family members' labor is remunerated at different wage rates $w_{1}$ and $w_{2}$ in the local labor market. ${ }^{9}$ Family members' labor supplies are perfect substitutes in the farm production $F$, which exhibits diminishing marginal productivity of labor $\left(F^{\prime}(0)=+\infty, F^{\prime}(L)>0, F^{\prime \prime}(L)<0\right)$. Other inputs such as land or capital are supposed to be fixed. Because the model focuses on the labor supply of non-migrant household members, I consider that the household does not hire non-family workers in the farm. This assumption does not modify the crucial predictions of the model, as I show in an extended version of the model presented in an online appendix. ${ }^{10}$

Let member 1 be the potential migrant and $w_{1}^{U S}$ the foreign wage rate. If he migrates, member 1 can no longer work in the family farm at the origin. Let $C$ be the monetary costs of migration (e.g. travel, housing and job search at destination) and let $\pi=\frac{C}{w_{1}^{U S} L_{1}^{U S}}$ be the costs expressed in foreign earnings-equivalent units $(0<\pi<1)$, with $L_{1}^{U S}$ member 1's working hours at destination. $\pi$ represents the fraction of foreign earnings that are forgone to meet migration costs. For modeling convenience, I assume that $\pi$ is constant. ${ }^{11}$ In addition to monetary costs, the separation of family members also entails psychological costs $\delta>0$, which I suppose additive in the family utility. To decide whether member 1 migrates, the household compares his indirect utilities with and without migration. The household optimization process can be

9. Wages are considered as exogenous in this partial equilibrium model because the migration of one individual does not affect the aggregate labor supply in the local labor market.

10. Refer to https://drive.google.com/file/d/0B41sfdueqjZKZV15b1o2VmZFSFk/view

11. This assumption allows bundling the costs and benefits of migration into one parameter $(1-\pi) w_{1}^{U S}$, i.e. the foreign wage net of migration costs. Imposing migration costs as being proportional to earnings at destination is admittedly a questionable assumption. However, the structure of migration costs and the resulting self-selection patterns into migration are not the focus of this model. 
expressed as a utility maximization in the following two labor regimes :

Member 1 stays $\begin{cases}\max _{c 1, c 2, L_{1}^{F}, L_{1}^{O}, L_{2}^{F}, L_{2}^{O}} & \theta U^{2}\left(c_{2}, T_{2}-L_{2}^{F}-L_{2}^{O}\right)+(1-\theta) U^{1}\left(c_{1}, T_{1}-L_{1}^{F}-L_{1}^{O}\right) \\ \text { subject to } & c_{1}+c_{2}=F\left(L_{1}^{F}+L_{2}^{F}\right)+w_{1} L_{1}^{O}+w_{2} L_{2}^{O}\end{cases}$

Member 1 migrates $\begin{cases}\max _{c 1, c 2, L_{1}^{O}, L_{2}^{F}, L_{2}^{O}} & \theta U^{2}\left(c_{2}, T_{2}-L_{2}^{F}-L_{2}^{O}\right)+(1-\theta) U^{1}\left(c_{1}, T_{1}-L_{1}^{O}\right)-\delta \\ \text { subject to } & c_{1}+c_{2}=F\left(L_{2}^{F}\right)+w_{1}^{*} L_{1}^{O}+w_{2} L_{2}^{O}\end{cases}$

with $w_{1}^{*}=(1-\pi) w_{1}^{U S}$ the foreign wage net of migration costs. The time constraints are $L_{i}^{F}+L_{i}^{O} \leq T_{i}$, for $i=1,2$. I assume that family members supply at least one unit of labor, i.e. $L_{i}^{F}+L_{i}^{O}>0$.

The Pareto weight $\theta$ reflects the relative bargaining power of the family members. In this setting, $\theta$ is constant and exogenous, which ensures that migration decisions are beneficial for the non-migrant member. This hypothesis will be tested in the data in the next sections. If migration were to reduce the bargaining power of the non-migrant member, he would possibly be worse-off after migration.

\subsection{Income effect through remittances}

To simplify the exposition of the income effect of migration, let me consider a landless household who only derives income from wage-earning labor $(F=0)$. The predictions of the model remain the same when farm production is introduced. For a formal proof, refer to the online appendix. The maximization of the utility of landless families can be then attained by a two-stage budgeting : in the first stage, household full-time income is allocated between members; And in the second stage, each individual independently maximizes his utility with respect to his own budget constraint. Let $R=w_{1} L_{1}-c_{1}$ denote the net transfer of member 1 to member 2 . If member 1 migrates, $R$ represents migrant's remittances. Subsequently, the program

$$
\left\{\begin{array} { l l } 
{ \operatorname { m a x } \theta U ^ { 2 } + ( 1 - \theta ) U ^ { 1 } } \\
{ \text { s.t. } c _ { 1 } + c _ { 2 } = w _ { 1 } L _ { 1 } + w _ { 2 } L _ { 2 } }
\end{array} \text { is equivalent to } \left\{\begin{array}{ll}
\max U^{1} & \max U^{2} \\
\text { s.t. } c_{1}=w_{1} L_{1}-R & \text { s.t. } c_{2}=w_{2} L_{2}+R
\end{array}\right.\right.
$$

with the optimal R such that $\theta U_{c_{2}}^{2}\left(R, w_{2}\right)=(1-\theta) U_{c_{1}}^{1}\left(R, w_{1}\right)$. Differentiating the last equation gives : $\frac{\partial R}{\partial w_{1}}=\frac{(1-\theta) \frac{\partial U_{c_{1}}^{1}}{\partial w_{1}}}{\theta \frac{\partial U_{c_{2}}^{2}}{\partial R}-(1-\theta) \frac{\partial U_{1}^{1}}{\partial R}}$ Because utilities are concave and leisure and consumption are complementary, it can be shown that $\frac{\partial U_{c_{1}}^{1}}{\partial w_{1}}<0 ; \frac{\partial U_{c_{1}}^{1}}{\partial R}>0$ and $\frac{\partial U_{c_{2}}^{2}}{\partial R}<0$. As a result, $\frac{\partial R}{\partial w_{1}}>0$ : the intra-household transfer increases with the wage rate of member 1 . In this unitary model of the family, member 1 shares any earnings gain with the other member 2 (corollary of income 
pooling). Since migration only occurs if the wage abroad is higher than the wage at home $\left(w_{1}^{*}>\right.$ $\left.w_{1}\right)$, this implies that the migrant remits at least his initial net contribution to the household income $\left(R\left(w_{1}^{*}\right)>R\left(w_{1}\right)\right)$. Note that if the migrant is initially a net taker of household resources - i.e. consumes more than he earns $(R<0)$ - he does not need to remit positive amounts to make the left-behinds better-off. In any case, migration increases the unearned income accruing to the non-migrant, thus raising his reservation wage. Since off-farm wages remain unaffected by migration, the non-migrant reduces his wage work in the labor market. The consumption of the non-migrant also unambiguously increases, as well as his utility.

\subsection{Substitution effect and total labor input in the farm}

Let me now introduce farm production. To fix ideas, I assume that member 1's wage is higher than member 2's, i.e. that $w_{2}=\alpha w_{1}$ with $0<\alpha<1$. The predictions essentially remain the same in the opposite case (see online appendix). The farm always demands a positive amount of labor input. Since family members are substitutes in the farm although member 1's off-farm wage is higher, efficiency requires that member 2 specializes in farming.

Figure 1 shows the optimal labor participation choices of member 1 depending on his wage and the marginal productivity of farm labor. When his wage $w_{1}$ is lower than the marginal productivity of the farm $\Omega$, member 1 only works in the farm. When his wage is sufficiently high $\left(w_{1}>\Omega\right)$, member 1 starts participating in the local labor market and the household equalizes the return of farm and off-farm work, i.e. $F^{\prime}\left(L^{F}\right)=w_{1}$. A marginal increase in member 1's wage reduces the total family labor devoted to the farm, given that it is now more efficient to reallocate labor to off-farm work. Note that his reallocation increases the household income pooled within the family. The same reasoning applies when member 1 migrates. Member 1 only leaves the farm if the foreign wage $w_{1}^{*}$ is sufficiently high. Since the earnings gains of migration are shared between the family members, member 2 does not need to completely replace the migrant's farm labor. Due to this income effect, the total family labor in the farm declines.

The marginal productivity of member 2's farm labor rises when member 1 - who initially worked in the farm - migrates. Due to this substitution effect, which has the opposite influence of the income effect on the non-migrant's farm labor, the impact of migration remains theoretically ambiguous. However, migration would not entail any substitution effect if the migrant were not working in the farm initially. In this case, the non-migrant's farm labor should decrease with migration. It may yet also remain unchanged in the case where the non-migrant initially participates in both farm and off-farm work. ${ }^{12}$

12. This can happen because for member 2, every infra-marginal unit of farm labor is more valuable than wage labor $\left(F^{\prime}\left(L_{2}^{F}\right)=w_{2}\right.$ and $\left.F^{\prime \prime}<0\right)$. Due to the income effect of migration, member 2 first reduces the type of labor whose marginal product is the lowest, i.e. wage labor. If the income effect is not sufficiently high, member 2 only 
FIGURE 1 - Marginal productivity of farm labor and member 1's wage

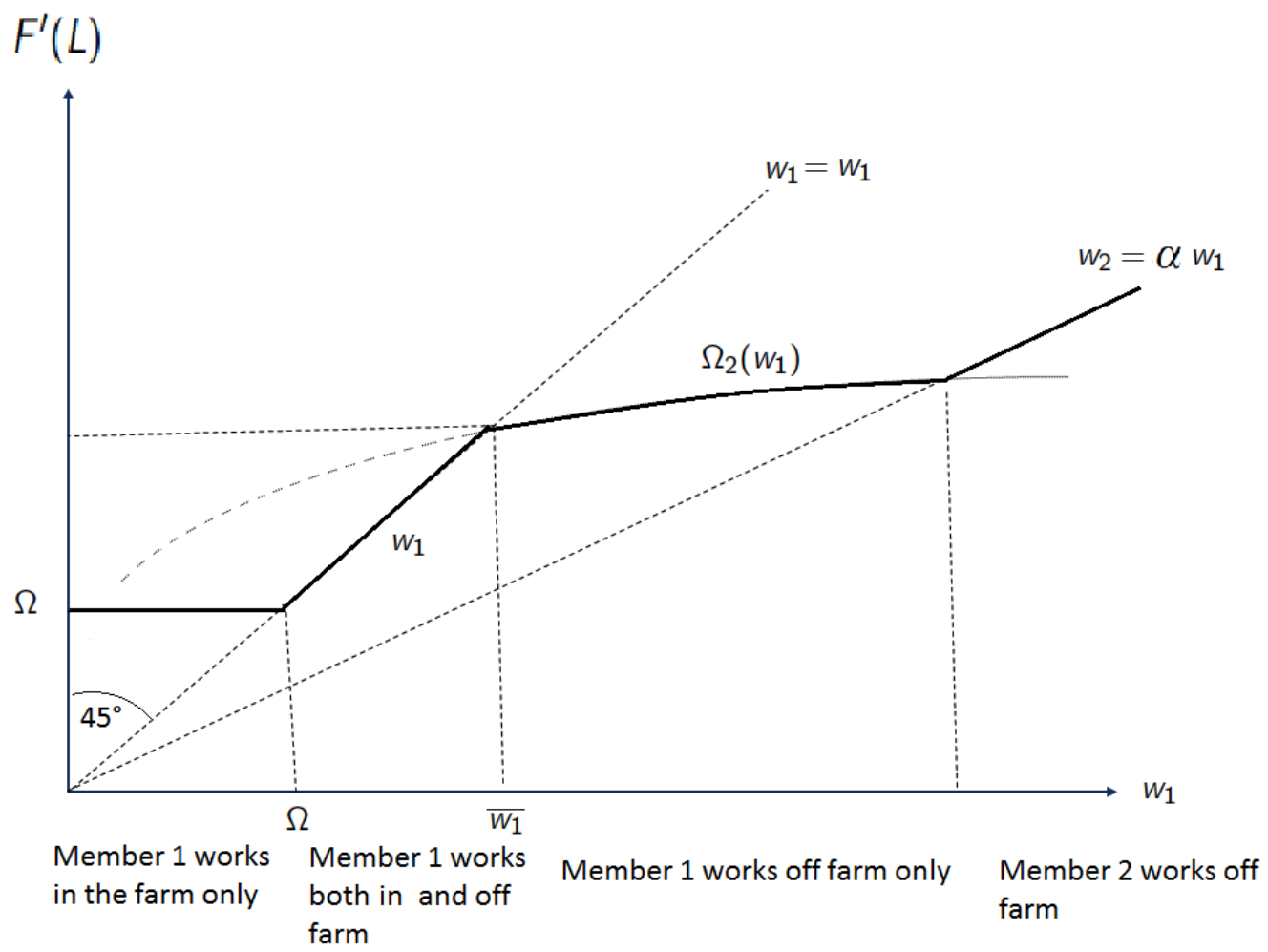

$\Omega$ is the marginal product of farm labor when member 1 works in the farm only. $\Omega_{2}$ is the marginal product of member 2's farm labor when he is the only farmer. $\Omega_{2}$ increases with $w_{1}$ and $\overline{w_{1}}$ is the (unique) intersection of $\Omega_{2}$. with the $45^{\circ}$ line. Furthermore, $\forall w_{1} \geq \overline{w_{1}}, \Omega_{2}\left(w_{1}\right)<w_{1}$. When $w_{1}<\Omega$, member 1 only works in the farm and $F^{\prime}\left(L^{F}\right)=\Omega$. When $\Omega<w_{1}<\overline{w_{1}}$, member 1 works both off-farm and in the farm and $F^{\prime}\left(L^{F}\right)=w_{1}$. When $\overline{w_{1}}<w_{1}$, member 1 stops working in the farm and $F^{\prime}\left(L^{F}\right)=\Omega_{2}\left(w_{1}\right)$. When member 2's wage $w_{2}>\Omega_{2}\left(w_{1}\right)$, member 2 works both off-farm and in the farm and $F^{\prime}\left(L^{F}\right)=w_{2}$.

\subsection{Testable predictions}

In summary, the theoretical model generates the following four predictions, necessarily implied by migration decisions taken to increase non-migrants' welfare :

1. Members left behind should reduce their labor in off-farm wage-earning jobs.

2. Due to the combination of the income and the substitution effect, the impact of migration on non-migrants' farm labor remains theoretically undetermined. However, the effect of migration should be more positive (or less negative) when the migrant initially worked in the farm than when he did not.

3. The total family labor devoted to the farm should decrease.

4. Non-migrants' consumption should increase.

reduces his off-farm work and holds constant his farm labor. 


\section{Data}

\subsection{The Mexican Family Life Survey}

I use the Mexican Family Life Survey (MxFLS), which is a longitudinal household survey representative at the national and regional level. The baseline survey was conducted from April to July 2002 and covered approximately 8,000 households in 16 Mexican states. I restrict the analysis to rural areas, defined as municipalities with fewer than 15,000 inhabitants. I use the rural sample of about 3,700 households with a complete questionnaire residing in 93 different municipalities (the majority of which have fewer than 2,500 inhabitants).

The second round of the survey began in mid-2005 and was completed in 2006, with a $95 \%$ re-contact rate at the household level. If an individual interviewed in the previous round is not found in the same household of origin, resident members of the household are asked about the location and date of departure of this individual. Therefore, even if they could not be individually re-contacted, all international migrants can be identified from the household roster. All sorts of migration to the U.S. can be observed, either legal or illegal, temporary or permanent.

The MxFLS asks the family left behind to provide the absentee's reason for moving out, for either employment or non-economic motives such as marriage, schooling or family reunification. Migrants leaving to seek better employment opportunities are males and females, respectively, less than 43 and 35 years old. Older men and women do not migrate for economic reasons. For the rest of the empirical analysis, I exclude single-person households and households in which no individual is within the age range of migrating (i.e. 12-43 years old). In fact, these households are extremely unlikely to send migrants by $2005 .{ }^{13}$

\section{Outcomes of interest}

For individuals older than 15 , the survey records the number of weekly hours worked in different activities during the last week preceding the interview : Non-agricultural salary work (obrero), agricultural wage-earning work (jornalero) and self-employed work. The latter category comprises peasants farming their plot, self-employed persons running a household-owned business and family workers without remuneration. In a different section of the questionnaire, the MxFLS collects time use data. Specifically, adult members are asked how many hours they spend per week on agricultural tasks (like weeding, hoeing, sowing, raising livestock) mainly performed in the family farm or garden. This information allows measuring hours allocated to unpaid family farm work. The MxFLS also collects farm income, profits of self-employed workers and earnings of wage earners during the month prior to the survey.

In order to compute a measure of individual non-durable consumption (per month), I use

13. This drops about $16 \%$ of the sample. My main results are robust to retaining them in the analysis. 
data on household expenditure on food consumption and non-food items (e.g. clothes, cleaning and cosmetic products, internet). I convert consumption at the household level into consumption at the individual level by dividing total expenditure by the same equivalence scale as Attanasio and Székely (2004) used in Mexico. ${ }^{14}$ I finally deflate all nominal values by using the CPI and convert them into 2002 values.

The MxFLS also asks each individual older than 15 the amount of private transfers (in cash or kind) that he receives from his non-co-resident family : either his parents, siblings or children. Although no specific question is asked about remittances, private transfers should include them in principle.

\section{Other variables}

The MxFLS also collects information on public transfers (e.g. pensions, Progresa, Procampo), household assets (e.g. financial savings, livestock and land) and household durable goods (e.g. vehicle, electronic appliances). Following the methodology of Filmer and Pritchett (2001) and McKenzie (2005), I construct a wealth index using principal component analysis with data on household assets and durable goods, as well as data on dwelling conditions and access to public utilities.

\subsection{Summary statistics}

Table 1 provides descriptive statistics of the sample of 2,642 households used in this study. Among those, 293 households (11\%) send at least one member to the U.S. between the two surveys rounds, i.e. between 2002 and 2005. Among the sample of 8,152 individuals older than 15,330 migrate to the U.S. during that period (4\%) and leave behind 753 non-migrant household members (9\%), while the rest of the respondents live in households that do not send U.S. migrants.

Panel A shows the average initial characteristics of households in 2002. Households that send migrants have generally more than five members prior to migration and are significantly larger than households without migrants. Despite having similar initial wealth, households with U.S. migrants appear to have lower consumption per adult equivalent relative to households without migrants. Migrant households seem to have lower labor income per capita and rely more on private transfers received from the extended family. Migrant households are also more likely to have relatives living in the U.S. at the time of the baseline survey in 2002, as well as having household members with past migration experience in the U.S.(i.e. former U.S. returnees).

As Panel B indicates, migrant individuals are typically young males around 23 years old, being generally the sons of the household head. The initial labor allocation across activities

14. Initially proposed by Contreras (1996), this adult equivalence scale takes into account economies of scale and different needs of different age groups. This scale gives a weight of 1.2 to the first adult, 0.8 to individuals 11 years of age or older, 0.4 to children aged 5-10 and 0.3 to children under the age of 5 . 
seems quite similar between households with and without migrants. In both types of households, around $50 \%$ of individuals participate in the labor force, with $20 \%$ working in nonagricultural jobs, $10 \%$ in agricultural jobs and $20 \%$ in self-employed activities. ${ }^{15}$ Around $15 \%$ of individuals works in the family farm, while $19 \%$ of the migrants do so. Note that participation in family farming - which comes from time use data - is not mutually exclusive with self-employed work or with wage work. When considering self-employment and farming together, I find that $33 \%$ of the migrants are engaged in some sort of household production. Migration is thus expected to increase the marginal productivity of non-migrants' self-employed labor in at least one-third of the migrant households.

\section{Empirical strategy}

\subsection{Specification}

To estimate how a household member's migration to the U.S. affects the labor supply and other outcomes of the non-migrants left behind, I estimate the following regression of outcome measure $Y_{\text {ihpt }}$ for individual $i$ in household $h$ residing in municipality $p$ at time $t$ :

$$
Y_{\text {ihpt }}=\beta . M i g U S_{h t}+\eta_{i}+\mu_{p}+\lambda_{t}+\lambda_{t} * \mu_{p}+\lambda_{t} * X_{i h} \alpha+\varepsilon_{i h t}
$$

where $M i g U S_{h t}$ is a binary equal to 1 if household $h$ has at least one member currently living in the U.S. at time $t$, and zero otherwise. The vector of individual fixed effects $\eta_{i}$ captures observed and unobserved time-invariant heterogeneity at the individual level. $\mu_{p}$ is a vector of fixed effects indicating the municipality of residence and $\lambda_{t}$ is a vector of year fixed effects. The interaction of year and municipal fixed effects $\lambda_{t} * \mu_{p}$ controls for municipal-specific timevarying shocks. The interaction $\lambda_{t} * X_{i h} \alpha$ controls for shocks or time trends that are specific to individuals and households with certain exogenous characteristics $X_{i h}$, determined prior to migration.

Since the MxFLS panel data only contains two rounds - one in 2002 and the other in 2005 — the specification takes the form of a difference-in-differences regression :

$$
\Delta Y_{i h p}=\beta . \Delta M i g U S_{h}+\Delta \lambda+\Delta \lambda \cdot \mu_{p}+X_{i h}(\alpha \Delta \lambda)+\Delta \varepsilon_{i h}
$$

where the operator $\Delta$ indicates first difference over time. The change in the household's migration status $\Delta M i g U S_{h}$ is a binary variable taking the value of one if a household member

15. This pattern appears in line with the finding of De Janvry and Sadoulet (2001) that Mexican rural households rely importantly on non-agricultural wages to complement their farm income. 
out-migrates to the U.S. between 2002 and 2005, and zero otherwise. ${ }^{16}$

Included in the vector $X_{i h}$ are pre-migration exogenous characteristics measured in 2002 : individual age, sex and education, the household size, the number of children and elderly persons in the household, the highest education attained in the household, a quadric form of wealth index and the amount of public transfers. To account for different time trends between households with and without migration networks or past migration experience in the U.S., the vector $X_{i h}$ includes two additional binary variables : one indicating whether the household has extended family living in the U.S. in 2002 and the other equal to 1 if a former U.S. returnee lives in the household in 2002. Finally, I cluster the standard errors at the household level to allow for correlations of the error terms $\Delta \varepsilon_{i h}$ within households. When the outcome of interest is measured at the household level - e.g. consumption per capita - I collapse the data by household and include only household-level characteristics in the controls.

In this specification, the reference group effectively contains individuals left behind by family members migrating internally within Mexico. I observe that about 5\% households have at least one member migrating to another Mexican municipality between 2002 and 2005. Whether or not I include the internal migration status of the household in the controls of equation (4) does not significantly alter the estimated impacts of international migration to the U.S. ${ }^{17}$

\subsection{Identification}

The principal threat to the identification of the causal impact of migration in equation (4) is the possibility of time-varying shocks to the household that affect both migration decisions and labor allocation (or other outcomes of interest). To address this concern, the regression includes a rich set of municipality-year fixed effects. On average, about 30 households are interviewed in each of the 93 different rural municipalities covered by the MxFLS. Since municipalities are small geographical areas in rural Mexico, these fixed effects control for unobserved shocks at a very local level, such as labor demand, agricultural or weather shocks.

However, it is possible that within municipalities, household-specific shocks constitute another source of endogeneity varying over time. For example, it could still be the case that due to a negative shock to the household income, the family is compelled to send a migrant abroad

16. In theory, $\Delta M i g U S_{h}$ can take three values $:+1$ if a member out-migrates, 0 if there is no change and -1 if a former U.S. migrant returns to the household of origin. In practice, extremely few cases of return migration to the same origin household are observed in the data (fewer than 20 households, i.e. $0.7 \%$ of the sample). For this reason - and because the impacts of out-migration and return migration may well be asymmetric — I choose to focus on the effects of out-migration to the U.S. The results are robust to whether or not I include a binary indicating return migration between 2002 and 2005 in the controls.

17. I do not examine the effects of domestic migration, because it is unclear whether it is part of an incomemaximizing strategy. The reasons behind internal migration (reported by left-behind members) are very heterogeneous and related to employment motives in less than $50 \%$ of the cases, while it is in more than $80 \%$ of the cases for U.S. migration. In addition, Antman (2012) finds suggestive evidence that domestic migrants do not earn significantly more than they would in their home villages. 
and reallocate its labor supply at the origin. I examine whether this problem is likely to bias the results by using data on shocks reported by the household head. I investigate whether shocks incurred by the household between the two survey rounds - i.e. 2002 and 2005 - influence the decision to send a migrant to the U.S. during the same period. As shown in table 2, I find that none of the five types of shocks - death or illness of a household member, job loss (or business failure), crop loss or property loss (house, animal, business) - significantly affect migration decisions between 2002 and 2005. Additionally, I explore whether shocks occurring before the baseline survey could influence migration in the subsequent years, thereby causing an artificially low (or high) initial outcome for households with future migrants. Table 2 shows that shocks between 1998 and 2002 have no significant effect on migration in the following years, which tends to rule out the possibility of a "Ashenfelter dip" type of bias. ${ }^{18}$

One criticism of this approach is that it relies on self-reported data and that unobserved time-varying factors could still invalidate the parallel-trend assumption necessary for identification. To address this problem, I examine whether pre-migration time trends in outcomes are similar between households with and without U.S. migrants. Because the MxFLS only provides two rounds, I draw upon the Mexican Labor Force Survey (ENOE), which follows each household for five consecutive quarters (with a rotating panel structure). To make the MxFLS and the ENOE samples comparable, I keep only rural municipalities with fewer than 15,000 inhabitants and use the years 2005, 2006 and 2007. ${ }^{19}$ Since migration can occur between the fourth and fifth interview, I can observe the labor allocation of households up to four quarters prior to migration. Figure 2 shows average differences in labor supply - in agricultural and non-agricultural jobs and self-employed work - between households with and without U.S. migrants one, two, three or four quarters prior to migration, controlling for municipality and quarter fixed effects. Although some significant differences in levels exist, they seem to remain stable over time, i.e. across quarters preceding migration. A formal test of parallel time trends before migration cannot be rejected, as table 8 in appendix shows (including individual fixed effects). This is also true when I examine earnings (wages or profits) of the household.

Accordingly, the inclusion of municipality fixed effects, combined with evidence that household shocks do not drive migration decisions and with the finding of parallel pre-trends within the year preceding migration suggests that a causal interpretation of the estimates is very plausible.

18. The estimates remain insignificant if I use shocks happening before 1998, or if I control for initial household characteristics in 2002. The percentage of households that declare having suffered from a shock varies from $3 \%$ to $8 \%$ depending on the type of the shock. See table 10 in the appendix.

19. Attrition is around $15 \%$ at the individual level after four quarters. I choose not to use the period 2002-2005 because it is covered by a different version of the Labor Force Survey (ENE) in which attrition is much higher (around 30\%-40\% after four quarters). Migration information is captured in the household roster, keeping track of who leaves the household in every period. The ENOE has been used in other studies to estimate out-migration flows from Mexico (Zenteno, 2011). 


\section{Results}

\subsection{Labor supply responses of non-migrants}

Panel A of table 3 presents estimates of the effect of U.S. migration on the labor force participation and weekly hours among non-migrant individuals older than 15. I find that U.S. migration significantly increases the probability of working in self-employed activities among left-behind household members by $5 \%$. Non-migrants spend more hours in self-employment $(+1.8 \mathrm{~h})$ and particularly family farm work $(+1.3 \mathrm{~h})$ as the result of the migration of a household member. There is no sign of an impact on total hours worked per week, which suggests that overall labor time has been reallocated rather than increased. Despite being insignificant, estimates regarding the effect on non-agricultural and agricultural jobs indicate that non-migrants may reduce their wage work.

Panel B of table 3 examines the effects on the total labor input in the household production, including both the migrant's and the non-migrants' labor. I measure total labor input by summing up individual hours (and participation) across all members living in the same household. Since this outcome does not vary within households, I collapse the data at the household level. The estimates suggest that U.S. migration tends to cause a decline in the total labor input in self-employed work, as well as farm work.

Table 3 thus reveals that non-migrants increase their self-employed labor but do not completely offset the loss of the migrant's labor. The finding that non-migrants do not totally replace migrant's farm labor is exactly in line with the income effect of migration predicted by the theoretical model.

\section{Direct evidence of substitution effect}

I now refine the specification to provide evidence on whether migration increases the marginal productivity of non-migrants' labor in self-employed activities, as well as in the farm in particular. For this purpose, I investigate the heterogeneity of the impacts depending on whether the migrant worked in self-employed activities prior to departure. Non-migrants living in households in which the migrant is initially self-employed can possibly work in the family production together with the migrant. By contrast, the group of households in which the migrant is not self-employed initially may include landless households without any means of production. Given that the presence of such households without farm nor business may generate bias in the estimation, I restrict the analysis to households where at least one member is engaged in self-employed activities in 2002.

The first column of table 4 shows that the effect of migration on non-migrants' self-employed labor is more positive when the migrant worked in the family production prior to departure than 
when he did not. When the migrant helped in the household production (40\% of the migrants do so), non-migrants are $10 \%$ more likely to participate in self-employment relative to when the migrant did not. The third and fourth columns replicate the same analysis by examining the differential impact according to whether the migrant worked on the family farm. I restrict the estimation sample to households initially engaged in farming. Among these, $45 \%$ of the migrants participate in farm work prior to migration. I find that when a farmer leaves the farm, the remaining members are $21 \%$ more likely to engage in agricultural tasks relative to when a non-farmer migrates. These findings provide direct evidence in favor of the substitution effect highlighted in the model.

Another possible explanation of the results is related to childcare and other domestic tasks. Since one potential childcare provider is absent after migration, the remaining family members may tend to shift labor towards types of self-employment that are complementary and more compatible with childcare and other household chores. Using time use data, I estimate how non-migrants adjust their time spent caring for children and elders and hours devoted to chores. As table 9 shows, I find no significant effects of U.S. out-migration on non-migrants' hours spent on domestic tasks, which suggests that this explanation is unlikely.

A second alternative explanation of the results pertains to indivisibilities in the agricultural production. Some farm inputs (e.g. livestock or seeds) may require fixed and lumpy amount of work (e.g. a farmer cannot milk half a cow or sow half a seed sack). This could explain why non-migrants increase their agricultural labor after the out-migration of a farmer. However, indivisibilities cannot account for the finding that migration is associated with a decrease in the total labor input in the farm (table 3). In fact, indivisibilities would normally require a constant amount of work devoted to the farm.

\subsection{Non-durable consumption and private transfers of non-migrants}

\section{Consumption gains}

I now study the effects of migration on non-durable consumption expenditure among the remaining household members at the origin. I proxy non-migrants' consumption using household consumption per adult equivalent, with the same equivalence scale as Attanasio and Székely (2004). The first two columns of table 5 show that U.S. migration generates a significant increase in food and non-food consumption between 2002 and 2005. Total consumption increases by about 222 pesos per household member per month in migrant-sending households, representing an increase of around $25 \%$ relative to households without migrants. ${ }^{20}$ This is similar to

20. When I use a continuous dependent variable representing an amount of pesos, I trim the estimation sample by dropping observations with values above the 99th percentile and below the 1st percentile. The trimming of the data avoids the results being driven by extreme outliers 
the $35 \%$ consumption gains from migration estimated by Bryan et al. (2014) with a randomized control trial in Bangladesh and by Beegle et al. (2011) for Tanzania. Since migration mechanically reduces the household size, it effectively reduces the denominator of the dependent variable (adult equivalent family size). I find that the results are robust to using different adult equivalent scales, which reflect different assumptions about the extent of economies of scale and heterogeneous needs across age and gender groups. ${ }^{21}$

Next, I examine whether the magnitude of consumption gains that I observe at the origin are in line with the amount that migrants remit. One distinctive feature of the MxFLS is that it tracked all 2002 baseline respondents who migrated to the U.S. between the two survey rounds, with a $91 \%$ re-contact rate in the U.S. (Teruel et al., 2012). Although individual-level data from the interviews of migrants in the U.S. has not yet been publicly released, the tables published in Farfan et al. (2013) provide some descriptive statistics. 65\% of MxFLS migrants remit, and those who remit send on average $3340 \$$ during the year prior to the interview, which represents around one-third of their U.S. earnings. This implies that families of migrants staying behind receive on average about 1,800 pesos a month, or 450 pesos per adult member for a typical migrant household. ${ }^{22}$

The MxFLS conducted in Mexico collects data on private transfers that each respondent receives from his non-co-resident family living either in Mexico or abroad. Table 5 shows that non-migrants are $6 \%$ more likely to receive any transfers as a result of the out-migration of a household member to the U.S. However, in terms of magnitude, non-migrants' transfers only seem to increase by 24 pesos a month on average, which is much lower than the amount that migrants declare remitting. Such a discrepancy might be due to the fact that recipients tend to under-report migrants' transfers (Seshan and Zubrickas, 2015; Seror, 2012). An alternative approach to avoid the problem of under-reporting is to look at the household unearned income calculated as the difference between total household consumption and total labor income realized at the origin, derived from self-employment or wages. The final column of table 5 indicates that U.S. migration is associated with an increase in the household unearned income by about 1,700 pesos a month, which seems closer in magnitude to the amount of remittances reported by MxFLS migrants in the U.S.

\section{Net income gains}

Had they not migrated, migrants would have contributed to the household income. In 2002, before migration occurs, $65 \%$ of the migrants participate in the labor force and earn a monthly wage of about 2,300 pesos on average. Assuming equal consumption among household mem-

21. In particular, using $\frac{C}{N^{\theta}}$ as the dependent variable, with $C$ the total household expenditure and $N$ the household size, I obtain very similar estimates of the migration impact for $\theta$ ranging from 0.5 to 1 .

22. On average, migrant households receive remittances inflows of $0.65 * 3340 / 12=181$ pesos a month, or 1,801 dollars a month (using OECD exchange rate data). 
bers, migrants consume on average 735 pesos, which implies that their net contribution to the household income amounts to $0.65 * 2300-735=760$ pesos a month. Thus, on average, migrants' remittances $(1,800$ pesos $)$ seem to exceed their forgone local income contribution by about 1,000 pesos.

Nonetheless, it is difficult to infer the counterfactual income that migrants would have earned at the origin, especially in households in which there is collective production on the farm. The observed increase in left-behinds' consumption could possibly still partly reflect the observed increase in their farm labor (recall that I estimate in table 4 that non-migrants' increase their farm work by about 2 hours a week due to U.S. migration). If non-migrants only consumed more because they worked more on the farm, it could hardly be concluded that they are better-off. However, the income generated by the 2 additional hours spent on the farm per week appears insufficient to account for the estimated 222 peso increase in consumption per month and per household member. Using hourly wages paid in the agricultural sector as a proxy for the marginal product of labor in the family farm reveals that the generated income is most likely to range from 25 to 140 pesos per month. ${ }^{23}$

\section{Direct evidence of income effect}

A direct approach to isolate the income effect of migration is to remove endogenous adjustments in labor supply and local earnings from consumption gains. Formally, noting $W_{2, t}$ and $c_{2, t}$ as the individual earnings and consumption of the non-migrants, I examine how migration affects $c_{2, t}-W_{2, t}$ between 2002 and 2005. However, it is difficult to distinguish between non-migrants' and migrants' individual labor income when they work together in the joint farm production. To circumvent this problem, I restrict the analysis to the sample of households that are not initially engaged in any self-employed activity in 2002. In this sub-sample, individuals only derive income from wages, in either agricultural or non-agricultural jobs.

Table 6 shows that U.S. migration increases non-durable consumption by about 314 pesos per household member left behind per month. Importantly, the local earnings of non-migrants at the origin decrease with the out-migration of a family member, which means that the income gains from migration are even higher than the consumption gains. Had they maintained their labor supply (and thus their earnings) constant, left-behinds could have consumed about 538 additional pesos per month ( 3 rd column), which represents a $66 \%$ consumption increase relative to households without migrants. Table 6 suggests that non-migrants instead prefer to reduce their working time, particularly in non-agricultural jobs.

23. Using the MxFLS in 2002, I find that the median hourly wage paid to agricultural workers (jornalero) is 8 pesos per hour, the 10th percentile is 3 pesos and the 90th percentile is 17 pesos. Using the 2000 Mexican census, I find a median of 6 pesos per hour, a 10th percentile of 3 pesos and a 90th percentile of 15 pesos per hour among agricultural workers living in the same rural municipalities as those covered by the MxFLS. 
In summary, I find evidence that migrants' remittances largely exceed their initial net income contribution to the origin household, which generates substantial income gains for the non-migrants. In households without a farm or business, left-behinds use this additional income to both consume more goods/services and increase their leisure time. Previous studies focusing on consumption gains may have underestimated the welfare gains of migration by ignoring the fact that non-migrants may substitute consumption with more leisure.

\subsection{Persistent effects on household durable assets and consumption}

Nonetheless, the observed increase in non-durable consumption among left-behinds might be financed by cutting down savings or selling durable assets. I thus examine how out-migration affects the ownership and the total reported value of some household durable goods and assets. Panel A of table 7 shows that U.S. out-migration tends to increase the stock of household durable resources between 2002 and 2005. In particular, migrant-sending households are more likely to own financial assets - e.g. savings in a bank account - to possess electronic appliances - e.g. TV, radio, computer — and have draft animals, such as horses or donkeys.

Using the third round of the MxFLS conducted in 2009/2010, I next explore how outmigration between 2002 and 2005 affects the variation in household assets between 2002 and 2009. ${ }^{24}$ Panel B of table 7 reveals that the effects over the 2002-2009 period are very similar to those over the 2002-2005 period. This suggests that the positive short-term effects of migration on household assets persist over time, at least 4 to 5 years after migration occurs.

In a similar way, in panel C I estimate the impact of 2002-2005 migration on the variation in non-durable consumption between 2002 and 2009. I find that U.S. migration increases nonmigrants' total consumption by about 162 pesos per household member per month, which is close to the 222 peso gain that U.S. migration is estimated to generate between 2002 and 2005 (table 5). This finding suggests that the positive short-term impact on non-migrants' consumption does not vanish over time. This is especially noticeable considering the fact that about one-third of 2002-2005 U.S. migrants return to the same MxFLS household of origin by 2009. As panel $\mathrm{C}$ shows, the reduction in the household size of migrant-sending households is significantly lower than between 2002 and 2009, which implies that some family members have joined or returned to the household between 2005 and 2009.

The finding of a positive and persistent impact of migration on households assets and consumption - despite the return of some migrants at a later stage — supports the view of Stark and Bloom (1985) and Stark (1991) of migration being a long-term family strategy to

24. Unfortunately, identifiers of MxFLS migrants between 2005 and 2009 are not available in the current database, so I cannot identify respondents who migrate between the second and third rounds. Therefore, I estimate the same specification as equation (4), with variation in the outcome between 2002 and 2009 rather than variation between 2002 and 2005 as the dependent variable. 
get out of poverty traps. Their theory argues that migration aims to alleviate capital and risk constraints to adopt higher-return production technologies at the origin. In rural Mexico, Taylor and Wyatt (1996) and Taylor and Lopez-Feldman (2010) find that remittances help to finance the accumulation of productive assets and raise land productivity among origin households. Woodruff and Zenteno (2007) and Massey and Parrado (1998) find that migration networks increase the investment and profits of Mexican microenterprises and even contribute to the formation of new businesses by providing a source of start-up capital. While the MxFS does not contain sufficiently detailed data to test this mechanism, the finding of an increase in livestock — and especially in draft animals — suggests that migration may cause higher investments in agricultural inputs at the origin.

\subsection{Robustness}

I evaluate the robustness of the results by looking at the sensitivity of the estimates of the migration effect to the exclusion of observed controls. I find that the results are robust to excluding the vector $X_{i h}$ of observed individual and household characteristics, as well as excluding the vector of municipal fixed effects.

Another possible concern may be attrition. The attrition rate is low - about $3.5 \%$ at the household level - and might be partly driven by whole-household migration to the U.S. Nonetheless, households that leave no members behind are not relevant here because my interest is in the population of households staying in the same community of origin in Mexico in the two rounds of the surveys. Among this population, there is no reason to expect that not being recorded in the second round of interview is systematically correlated with the out-migration of a household member to the U.S. ${ }^{25}$

25. Formally, in the conventional setup of Heckman (1979), noting $\Delta Y^{*}$ the unobserved outcome in the population of interest and $S^{*}$ the latent propensity to be interviewed in the second survey round :

$$
\begin{aligned}
\Delta Y^{*} & =\beta . \Delta \operatorname{Mig} U S+X \pi_{1}+u \\
S^{*} & =\alpha . \Delta \operatorname{Mig} U S+X \pi_{2}+v \\
\Delta Y & =\mathbb{1}\left\{S^{*} \geq 0\right\} . \Delta Y^{*}
\end{aligned}
$$

where $\triangle M i g U S$ is assumed to be exogenous, i.e. independent of $(u, v)$, conditional on $X$. Subsequently, the assumption that migration has no causal effect on attrition - i.e. $\alpha=0-$ implies that the effect of migration is correctly identified using the observed sample of non-attriters : $E\left[\Delta Y \mid \Delta M i g U S=1, S^{*}>0, X\right]-E\left[\Delta Y_{i h} \mid \Delta M i g U S=\right.$ $\left.0, S^{*}>0, X\right]=\beta$ 


\section{Conclusion}

There is no clear consensus about the welfare impact of international migration on those left behind, despite the magnitude of migration outflows from some developing countries and rural areas in particular. Previous literature has produced inconclusive evidence : some studies show that migration increases non-migrants' consumption while others suggest that these consumption gains may come at the expenses of a reduction in leisure time. This paper provides a new unified framework that allows testing whether migration increases non-migrants' welfare in terms of both consumption and leisure.

Using panel data in rural Mexico and controlling for fixed individual heterogeneity, I find that migration to the U.S. increases the food and non-food expenditure of household members staying behind by about $25 \%$. The main contribution of this study is to show that these consumption gains cannot be explained by endogenous adjustments in non-migrants' labor supply. This result establishes that U.S. migration improves the welfare of the family left behind in Mexico when the utility of consumption and the disutility of work are both taken into account.

I find evidence of two different channels through which migration positively affects nonmigrants' welfare. First, migrants' remittances appear to exceed their forgone income contribution to the origin household, thereby generating net income gains for those left behind. Second, non-migrants slightly increase their farm labor (in self-employment), especially when the migrant worked in the farm prior to departure. This indicates that in a context of decreasing marginal labor productivity in the agricultural production, a farmer's out-migration is likely to increase the marginal productivity of labor for those staying behind in the farm.

The combination of these positive income and substitution effects makes non-migrants better-off in the short term, as well as the longer term. I find that the consumption gains of those left behind persist over time - up to 5 years after migration - and despite the return of some migrants. In addition, migration seems to lead to higher accumulation of household durable assets at the origin, in the form of financial savings and livestock.

Contrary to other contexts (e.g. Tonga), migration from rural Mexico appears to work as a cooperative family strategy that benefits not only the migrant but also the members left behind at the origin. This result is consistent with the theory of Stark and Bloom (1985), which views migration as an intrafamilial implicit contract relying on mutual interdependence and providing mutual benefits to the migrant and the rest of the family. Nonetheless, it would be necessary to examine indicators of well-being other than consumption and leisure to obtain a better understanding of the welfare effect of migration. For example, the prolonged separation of close family members may entail psychological costs and increase the risks of mental health disorders. These other types of welfare costs related to migration may contribute to explain why more people do not migrate when the income gains of doing so seem high. 


\section{References}

Adams, R. H. (2011). Evaluating the Economic Impact of International Remittances On Developing Countries Using Household Surveys : A Literature Review. Journal of Development Studies 47(6), 809-828.

Ambler, K. (2015). Don't tell on me : Experimental evidence of asymmetric information in transnational households. Journal of Development Economics 113, 52-69.

Amuedo-Dorantes, C. and S. Pozo (2006). Migration, remittances, and male and female employment patterns. The American economic review 96(2), 222-226.

Amuedo-Dorantes, C. and S. Pozo (2011). Remittances and income smoothing. The American Economic Review 101(3), 582-587.

Antman, F. (2013). The impact of migration on family left behind. In K. F. Zimmermann and A. Constant (Eds.), International Handbook on the Economics of Migration. Cheltenham, UK : Edward Elgar Publishing Limited.

Antman, F. M. (2010). Adult child migration and the health of elderly parents left behind in mexico. The American economic review 100(2), 205.

Antman, F. M. (2011). The intergenerational effects of paternal migration on schooling and work: What can we learn from children's time allocations? Journal of Development Economics 96(2), 200-208.

Antman, F. M. (2012). Gender, educational attainment, and the impact of parental migration on children left behind. Journal of Population Economics 25(4), 1187-1214.

Ashraf, N., D. Aycinena, C. Martínez A, and D. Yang (2015). Savings in transnational households : a field experiment among migrants from el salvador. Review of Economics and Statistics 97(2), 332351.

Attanasio, O. P. and M. Székely (2004). Wage shocks and consumption variability in mexico during the 1990s. Journal of Development Economics 73(1), 1-25.

Beegle, K., J. De Weerdt, and S. Dercon (2011). Migration and economic mobility in tanzania : Evidence from a tracking survey. Review of Economics and Statistics 93(3), 1010-1033.

Bertoli, S. and F. Marchetta (2014). Migration, remittances and poverty in Ecuador. Journal of Development Studies 50(8).

Binzel, C. and R. Assaad (2011). Egyptian men working abroad : Labour supply responses by the women left behind. Labour Economics 18, S98-S114.

Bryan, G., S. Chowdhury, and A. M. Mobarak (2014). Underinvestment in a profitable technology : The case of seasonal migration in bangladesh. Econometrica 82(5), 1671-1748.

Chang, H., X. yuan Dong, and F. MacPhail (2011). Labor migration and time use patterns of the leftbehind children and elderly in rural China. World Development 39(12), 2199-2210.

Chen, J. J. (2013). Identifying non-cooperative behavior among spouses : child outcomes in migrantsending households. Journal of Development Economics 100(1), 1-18.

Clemens, M. A. (2013). Why do programmers earn more in houston than hyderabad ? evidence from randomized processing of us visas. The American Economic Review 103(3), 198-202.

Contreras, D. (1996). Household and individual welfare : evidence from less developed economies. Working Paper, University of California, Los Angeles. Mimeo.

Cox-Edwards, A. and E. Rodríguez-Oreggia (2009). Remittances and Labor Force Participation in 
Mexico : An Analysis Using Propensity Score Matching. World Development 37(5), 1004-1014.

De Janvry, A. and E. Sadoulet (2001). Income strategies among rural households in Mexico : The role of off-farm activities. World development 29(3).

de la Fuente, A. (2010). Remittances and vulnerability to poverty in rural Mexico. World Development 38(6), 828-839.

De Laat, J. (2014). Household allocations and endogenous information : The case of split migrants in kenya. Journal of Development Economics 106, 108-117.

Démurger, S. and S. Li (2013). Migration, Remittances, and Rural Employment Patterns : Evidence from China (Emerald Group Publishing Limited ed.)., pp. 31 - 63. Labor Market Issues in China (Research in Labor Economics, Volume 37).

Drapier, C., H. Jayet, and H. Rapoport (2006). On the law of return in rural-urban interactions : An economic approach to solidarity with return migrants. The Economics of Immigration and Social Diversity (Research in Labor Economics, Volume 24), 427-448.

Farfan, G., M. Genoni, L. Rubalcava, G. Teruel, D. Thomas, and A. Velasquez (2013). International transfers by mexican migrants in the united states. unpublished manuscript.

Filmer, D. and L. Pritchett (2001). Estimating Wealth Effects Without Expenditure Data . Or Tears : An Application To Educational Enrollments In States Of India. Demography 38(1), 115-132.

Gibson, J. and D. McKenzie (2012). The economic consequences of 'brain drain' of the best and brightest : Microeconomic evidence from five countries. The Economic Journal 122(560), 339-375.

Gibson, J., D. McKenzie, and S. Stillman (2011). The impacts of international migration on remaining household members : omnibus results from a migration lottery program. Review of Economics and Statistics (202).

Hanson, G. (2007). Emigration, remittances, and labor force participation in Mexico. Integration and Trade Journal 27(2005), 73-105.

Heckman, J. J. (1979). Sample selection bias as a specification error. Econometrica 47(1), 153-161.

Lokshin, M. and E. Glinskayai (2008). The effect of male migration for work on employment patterns of females in Nepal. World Bank Policy Research Working Paper (October).

Massey, D. S. and E. A. Parrado (1998). International Migration and Business Formation in Mexico. Social Science Quarterly 79(1), 1-20.

McKenzie, D. (2005). Measuring inequality with asset indicators. Journal of Population Economics 18(2), 229-260.

McKenzie, D. and H. Rapoport (2007). Network effects and the dynamics of migration and inequality : Theory and evidence from Mexico. Journal of Development Economics 84(1), 1-24.

McKenzie, D. and H. Rapoport (2011). Can migration reduce educational attainment ? Evidence from Mexico. Journal of Population Economics 24(4), 1331-1358.

McKenzie, D., S. Stillman, and J. Gibson (2010). How important is selection? experimental vs. nonexperimental measures of the income gains from migration. Journal of the European Economic Association 8(4), 913-945.

Mendola, M. and C. Carletto (2012). Migration and gender differences in the home labour market : Evidence from Albania. Labour Economics 19(6), 870-880.

Mishra, P. (2007). Emigration and wages in source countries : Evidence from mexico. Journal of Development Economics 82(1), 180-199. 
Mu, R. and D. van de Walle (2011). Left behind to farm? Women's labor re-allocation in rural China. Labour Economics 18, S83-S97.

Sadoulet, E., A. De Janvry, and C. Benjamin (1998). Household behavior with imperfect labor markets. Industrial Relations : A Journal of Economy and Society 37(1), 85-108.

Schiff, M. (2008). On the underestimation of migration's income and poverty impact. Review of Economics of the Household 6(3), 267-284.

Seror, M. (2012). Measuring information asymmetries and modeling there impact on senegalese migrants' remittances.

Seshan, G. and R. Zubrickas (2015). Asymmetric information about migrant earnings and remittance flows. The World Bank Economic Review.

Stark, O. (1991). The migration of labor. Oxford : Blackwell.

Stark, O. and D. E. Bloom (1985). The new economics of labor migration. The American Economic Review 75(2), pp. 173-178.

Taylor, J. E. and I. Adelman (2003). Agricultural household models : genesis, evolution, and extensions. Review of Economics of the Household 1(1-2), 33-58.

Taylor, J. E. and A. Lopez-Feldman (2010). Does Migration Make Rural Households More Productive? Evidence from Mexico. Journal of Development Studies 46(1), 68-90.

Taylor, J. E. and T. J. Wyatt (1996). The shadow value of migrant remittances, income and inequality in a household-farm economy. The Journal of Development Studies 32(6), 899-912.

Teruel, G., E. Arenas, and L. Rubalcava (2012). Migration in the Mexican Family Life Survey. In Migration and Remittances : Trends, Impacts and New Challenges (Rowman and ed.).

Woodruff, C. and R. Zenteno (2007). Migration networks and microenterprises in Mexico. Journal of Development Economics 82(2), 509-528.

Zenteno, R. (2011). Recent trends in mexican migration to the us : The mexico perspective. In Paper presented at 2011 Annual Population Association of America Meeting, Washington, DC. 
TABLE 1 - Household and individual initial characteristics in 2002 across migration status

\begin{tabular}{|c|c|c|c|c|}
\hline \multicolumn{5}{|l|}{ Panel A : sample of households } \\
\hline \multirow[b]{2}{*}{ Pre-migration characteristics in 2002} & \multicolumn{2}{|c|}{$\begin{array}{c}\text { Households } \\
\text { without migrants }\end{array}$} & \multicolumn{2}{|c|}{$\begin{array}{c}\text { Households } \\
\text { with migrants }{ }^{a}\end{array}$} \\
\hline & & & & \\
\hline household size & 4.90 & $(1.94)$ & $6.04^{* *}$ & $(2.29)$ \\
\hline hhsize $=1$ & 0.00 & $(0.00)$ & 0.00 & $(0.00)$ \\
\hline hhsize $=2$ & 0.06 & $(0.24)$ & $0.01^{* *}$ & $(0.08)$ \\
\hline hhsize $=3$ & 0.17 & $(0.38)$ & $0.11^{* *}$ & $(0.31)$ \\
\hline hhsize $=4$ & 0.25 & $(0.43)$ & $0.18^{* *}$ & $(0.39)$ \\
\hline hhsize $\geq 5$ & 0.52 & $(0.50)$ & $0.71^{* *}$ & $(0.46)$ \\
\hline nb children $<13$ yold & 1.76 & $(1.51)$ & $2.14^{* *}$ & $(1.72)$ \\
\hline nb elderly $>55$ yold & 0.43 & $(0.72)$ & 0.45 & $(0.68)$ \\
\hline Highest degree in hh: secondary school & 0.40 & $(0.49)$ & $0.46^{*}$ & $(0.50)$ \\
\hline Highest degree in hh : post-secondary school & 0.18 & $(0.39)$ & $0.14^{*}$ & $(0.35)$ \\
\hline Wealth index (PCA) & -0.36 & $(1.97)$ & -0.21 & $(1.89)$ \\
\hline family network in the U.S. & 0.47 & $(0.50)$ & $0.76^{* *}$ & $(0.43)$ \\
\hline U.S. returnees at home & 0.05 & $(0.21)$ & $0.13^{* *}$ & $(0.34)$ \\
\hline \multicolumn{5}{|l|}{ Monthly consumption per adult equivalent } \\
\hline Food items & 571.09 & $(365.57)$ & $516.59^{* *}$ & $(376.19)$ \\
\hline Non-Food items & 237.63 & $(217.18)$ & $210.73^{* *}$ & $(195.73)$ \\
\hline Total consumption & 822.78 & $(557.69)$ & $736.59^{* *}$ & $(538.19)$ \\
\hline \multicolumn{5}{|l|}{ Monthly household income per capita } \\
\hline Labor Income & 697.01 & $(809.44)$ & $550.95^{* *}$ & $(704.58)$ \\
\hline Public transfers & 46.63 & (80.30) & 47.86 & (73.39) \\
\hline Private transfers & 30.95 & (88.90) & $53.98^{* *}$ & $(126.82)$ \\
\hline Observations & & 349 & & \\
\hline
\end{tabular}

\section{Panel B : sample of individuals older than 15}

Individuals living in :

Households

Households with migrants

\begin{tabular}{lccccccccc} 
& \multicolumn{2}{c}{ without migrants } & \multicolumn{3}{c}{ All members ${ }^{b}$} & Non-migrants & \multicolumn{3}{c}{ Migrants } \\
\cline { 5 - 9 } & & & & & & & & \\
Age & 35.90 & $(16.45)$ & $33.68^{* *}$ & $(16.41)$ & 38.29 & $(16.91)$ & 23.15 & $(8.53)$ \\
Male & 0.47 & $(0.50)$ & 0.47 & $(0.50)$ & 0.37 & $(0.48)$ & 0.68 & $(0.47)$ \\
Years of education & 5.80 & $(3.87)$ & $5.56^{*}$ & $(3.61)$ & 4.86 & $(3.64)$ & 7.18 & $(2.98)$ \\
Household head & 0.33 & $(0.47)$ & $0.27^{* *}$ & $(0.44)$ & 0.31 & $(0.46)$ & 0.18 & $(0.39)$ \\
Spouse & 0.27 & $(0.44)$ & $0.20^{* *}$ & $(0.40)$ & 0.28 & $(0.45)$ & 0.02 & $(0.13)$ \\
Son & 0.16 & $(0.36)$ & $0.21^{* *}$ & $(0.41)$ & 0.11 & $(0.32)$ & 0.45 & $(0.50)$ \\
Daughter & 0.15 & $(0.36)$ & $0.20^{* *}$ & $(0.40)$ & 0.19 & $(0.39)$ & 0.23 & $(0.42)$ \\
& & & & & & & & \\
Work last week & 0.54 & $(0.50)$ & $0.50^{* *}$ & $(0.50)$ & 0.43 & $(0.50)$ & 0.65 & $(0.48)$ \\
Non-agricultural wage work & 0.23 & $(0.42)$ & $0.19^{* *}$ & $(0.39)$ & 0.14 & $(0.35)$ & 0.29 & $(0.45)$ \\
Agricultural wage work & 0.11 & $(0.31)$ & $0.08^{* *}$ & $(0.27)$ & 0.05 & $(0.22)$ & 0.14 & $(0.35)$ \\
Self-employed work & 0.19 & $(0.39)$ & $0.23^{* *}$ & $(0.42)$ & 0.24 & $(0.43)$ & 0.22 & $(0.42)$ \\
Participation in family farming & 0.14 & $(0.35)$ & 0.15 & $(0.36)$ & 0.13 & $(0.34)$ & 0.19 & $(0.39)$ \\
& & & & & & & & \\
\end{tabular}

\section{Observations}

7069

Notes : Migrants are individuals emigrating to the U.S. between 2002 and 2005 . Participation in family farming is not mutually exclusive with any type of work status. Standard deviations in parentheses. ${ }^{a},{ }^{b}:$ stars indicate that the difference in mean between households with and without migrants is statistically significant. Significance level : *p $<0.10, * * p<0.05$. 
TABLE 2 - Determinants of U.S. out-migration between 2002 and 2005 at the household level

\begin{tabular}{|c|c|c|c|c|}
\hline Dependent variable : & \multicolumn{4}{|c|}{ Out-migration to the U.S. betw. 2002-2005 in the household } \\
\hline \multicolumn{5}{|l|}{ Household shocks between 2002 and 2005} \\
\hline Death of a household member & $\begin{array}{l}-0.033 \\
(0.024)\end{array}$ & $\begin{array}{c}-0.022 \\
(0.025)\end{array}$ & & \\
\hline Illness of a household member & $\begin{array}{c}-0.022 \\
(0.021)\end{array}$ & $\begin{array}{l}-0.024 \\
(0.022)\end{array}$ & & \\
\hline Job loss or Business failure & $\begin{array}{l}-0.018 \\
(0.031)\end{array}$ & $\begin{array}{l}-0.011 \\
(0.032)\end{array}$ & & \\
\hline Crop Loss & $\begin{array}{l}-0.041 \\
(0.028)\end{array}$ & $\begin{array}{l}-0.036 \\
(0.028)\end{array}$ & & \\
\hline House $\backslash$ business $\backslash$ animals loss & $\begin{array}{c}0.049 \\
(0.035)\end{array}$ & $\begin{array}{c}0.053 \\
(0.036)\end{array}$ & & \\
\hline \multicolumn{5}{|l|}{ Household shocks between 1998 and 2002} \\
\hline Death of a household membe & & & $\begin{array}{l}-0.002 \\
(0.038)\end{array}$ & $\begin{array}{c}-0.004 \\
(0.038)\end{array}$ \\
\hline Illness of a household memberr & & & $\begin{array}{c}-0.013 \\
(0.019)\end{array}$ & $\begin{array}{c}-0.009 \\
(0.020)\end{array}$ \\
\hline Job loss or Business failure & & & $\begin{array}{c}0.039 \\
(0.024)\end{array}$ & $\begin{array}{l}0.042 * \\
(0.025)\end{array}$ \\
\hline Crop Loss & & & $\begin{array}{l}-0.023 \\
(0.020)\end{array}$ & $\begin{array}{c}-0.013 \\
(0.021)\end{array}$ \\
\hline House $\backslash$ business $\backslash$ animals loss & & & $\begin{array}{l}-0.010 \\
(0.028)\end{array}$ & $\begin{array}{c}-0.002 \\
(0.029)\end{array}$ \\
\hline \multicolumn{5}{|l|}{ Initial household characteristic in 2002} \\
\hline household size & $\begin{array}{c}0.032 * * * \\
(0.006)\end{array}$ & & $\begin{array}{c}0.032 * * * \\
(0.006)\end{array}$ & \\
\hline nb children $<13$ yold & $\begin{array}{c}-0.017 * * * \\
(0.007)\end{array}$ & & $\begin{array}{c}-0.017 * * * \\
(0.006)\end{array}$ & \\
\hline nb elderly $>55$ yold & $\begin{array}{c}0.001 \\
(0.012)\end{array}$ & & $\begin{array}{c}0.001 \\
(0.012)\end{array}$ & \\
\hline nb male $14-35$ & $\begin{array}{c}0.023 * * * \\
(0.009)\end{array}$ & & $\begin{array}{c}0.023 * * * \\
(0.009)\end{array}$ & \\
\hline Highest education in hh : secondary & $\begin{array}{c}0.036^{* * *} \\
(0.014)\end{array}$ & & $\begin{array}{c}0.038 * * * \\
(0.014)\end{array}$ & \\
\hline Highest education in hh : post-secondary & $\begin{array}{c}0.004 \\
(0.019)\end{array}$ & & $\begin{array}{c}0.004 \\
(0.019)\end{array}$ & \\
\hline Wealth index & $\begin{array}{c}0.003 \\
(0.005)\end{array}$ & & $\begin{array}{c}0.003 \\
(0.005)\end{array}$ & \\
\hline Squared wealth index & $\begin{array}{c}0.001 \\
(0.001)\end{array}$ & & $\begin{array}{c}0.001 \\
(0.001)\end{array}$ & \\
\hline Household public transfers $(\log )$ & $\begin{array}{c}-0.001 \\
(0.002)\end{array}$ & & $\begin{array}{l}-0.001 \\
(0.002)\end{array}$ & \\
\hline Household with relatives in US & $\begin{array}{l}0.025 * \\
(0.014)\end{array}$ & & $\begin{array}{l}0.025 * \\
(0.014)\end{array}$ & \\
\hline Household with US returnees & $\begin{array}{l}0.047 * \\
(0.026)\end{array}$ & & $\begin{array}{l}0.048 * \\
(0.026)\end{array}$ & \\
\hline Municipality Fixed Effects & YES & YES & YES & YES \\
\hline $\mathrm{R}^{2}$ & 0.21 & 0.17 & 0.21 & 0.17 \\
\hline $\mathrm{N}$ & 2,608 & 2,608 & 2,608 & 2,608 \\
\hline
\end{tabular}

Notes : Standard errors in parentheses (). Significance level : ${ }^{*} p<0.10, * * p<0.05, * * * p<0.01$. 
TABLE 3 - Labor reallocation effects among left behind household members

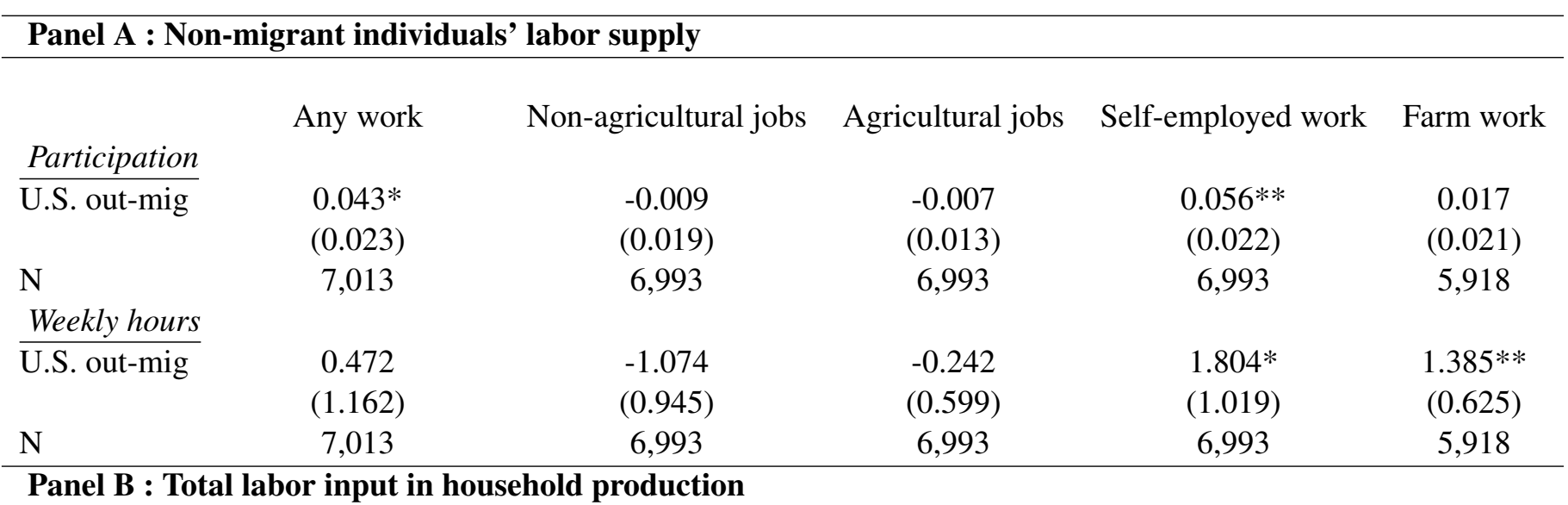

Panel B : Total labor input in household production

Self-employed work $\quad$ Farm work

Number of workers

\begin{tabular}{|c|c|c|}
\hline U.S. out-mig & $\begin{array}{l}-0.103 * \\
(0.061)\end{array}$ & $\begin{array}{c}-0.145^{* *} \\
(0.070)\end{array}$ \\
\hline $\mathrm{N}$ & 2,640 & 2,640 \\
\hline Total hours $p$ & & \\
\hline U.S. out-mig & $\begin{array}{l}-4.956^{*} \\
(2.769)\end{array}$ & $\begin{array}{l}-1.871 \\
(1.771)\end{array}$ \\
\hline $\mathrm{N}$ & 2,640 & 2,640 \\
\hline
\end{tabular}

Notes : In panel A, the sample includes all non-migrant individuals older than 15. In panel B, the data is collapsed at the household level. Standard errors in parentheses (). Std. errors clustered at the household level. Significance level : $* p<0.10, * * p<0.05$, *** $p<0.01$. Controls of the regressions include : municipality fixed effects, individual age, sex and education, household size and demographic composition, highest education attained in the household, a quadric form of wealth index, the amount of public transfers, extended family networks in the U.S. and returnees living in the household.

TABLE 4 - Labor reallocation effects among left-behinds depending on initial migrant's occupation

\begin{tabular}{|c|c|c|c|c|}
\hline & \multicolumn{2}{|c|}{ Self-employed work } & \multicolumn{2}{|c|}{ Farm work } \\
\hline & participation & weekly hours & participation & weekly hours \\
\hline U.S. out-mig & $\begin{array}{c}0.022 \\
(0.035)\end{array}$ & $\begin{array}{c}1.563 \\
(1.885)\end{array}$ & $\begin{array}{c}-0.081 * \\
(0.043)\end{array}$ & $\begin{array}{l}3.084 * \\
(1.624)\end{array}$ \\
\hline U.S. out-mig * migrant self-employed & $\begin{array}{c}0.107 * * \\
(0.054)\end{array}$ & $\begin{array}{c}1.904 \\
(2.561)\end{array}$ & & \\
\hline U.S. out-mig * migrant farmer & & & $\begin{array}{c}0.210 * * * \\
(0.072)\end{array}$ & $\begin{array}{c}0.151 \\
(2.356)\end{array}$ \\
\hline $\mathrm{N}$ & 3,382 & 3,302 & 2,091 & 2,076 \\
\hline
\end{tabular}


TABLE 5 - Non-durable consumption and private transfers received by non-migrant individuals

\begin{tabular}{|c|c|c|c|c|c|c|}
\hline & \multicolumn{3}{|c|}{$\begin{array}{l}\text { Non-durable consumption } \\
\text { per adult equivalent }{ }^{a}\end{array}$} & \multicolumn{2}{|c|}{$\begin{array}{c}\text { Individual private transfers } \\
\text { of non-migrants }\end{array}$} & \multirow[t]{2}{*}{$\begin{array}{l}\text { Household unearned } \\
\text { income }^{b}\end{array}$} \\
\hline & Food & Non-food & Total & Receive $=1$ & Amount & \\
\hline U.S. out-Mig & $\begin{array}{l}94.487 * * * \\
(29.288)\end{array}$ & $\begin{array}{c}88.206^{* * *} \\
(18.901)\end{array}$ & $\begin{array}{l}222.216 * * * \\
(44.694)\end{array}$ & $\begin{array}{l}0.063 * * \\
(0.028)\end{array}$ & $\begin{array}{r}24.164 * * \\
(10.412)\end{array}$ & $\begin{array}{c}1,734.137 * * * \\
(297.547)\end{array}$ \\
\hline $\mathrm{N}$ & 2,495 & 2,549 & 2,538 & 5,780 & 5,896 & 2,526 \\
\hline 2002 mean & 584.513 & 248.179 & 843.339 & 0.224 & 42.624 & 281.42 \\
\hline
\end{tabular}

Notes : ${ }^{a}$ equal to the total household expenditure per month divided by the adult equivalence scale used in Attanasio and Székely (2004). ${ }^{b}$ is equal to the total household consumption minus the total labor income derived from self-employment or wages. Standard errors in parentheses (). Std. errors clustered at the household level. Significance level : * $p<0.10, * * p<0.05, * * * p<0.01$. The controls of the regressions are the same as included in table 3 .

TABLE 6 - Direct evidence of income effect of migration

\begin{tabular}{|c|c|c|c|c|c|c|c|}
\hline & \multirow{2}{*}{$\begin{array}{l}\text { Consumption } \\
\text { per adu. equiv. }{ }^{a}\end{array}$} & \multirow{2}{*}{$\begin{array}{l}\text { Individual earnings } \\
\text { of non-migrants } b\end{array}$} & \multirow{2}{*}{$\begin{array}{l}\text { Net income } \\
\text { gains }^{c}\end{array}$} & \multicolumn{2}{|c|}{ Non-agri. jobs } & \multicolumn{2}{|c|}{ Agri. jobs } \\
\hline & & & & part. & hours & part. & hours \\
\hline U.S. out-Mig & $\begin{array}{c}314.773 * * * \\
(63.290)\end{array}$ & $\begin{array}{l}-288.738 * * * \\
(97.554)\end{array}$ & $\begin{array}{l}538.738 * * * \\
(98.542)\end{array}$ & $\begin{array}{l}-0.031 \\
(0.032)\end{array}$ & $\begin{array}{c}-3.227 * * \\
(1.615)\end{array}$ & $\begin{array}{c}0.015 \\
(0.025)\end{array}$ & $\begin{array}{c}0.551 \\
(1.141)\end{array}$ \\
\hline $\mathrm{N}$ & 1,373 & 3,584 & 3,473 & 3,611 & 3,555 & 3,611 & 3,555 \\
\hline 2002 mean & 802.734 & 871.977 & -75.805 & 0.311 & 14.015 & 0.156 & 6.726 \\
\hline
\end{tabular}

Notes : The sample is restricted to households that are not initially engaged in any self-employed activity in $2002 .{ }^{a}$ equal to the total household expenditure per month divided by the adult equivalence scale used in Attanasio and Székely (2004). ${ }^{b}$ is equal to the individual earnings per month of non-migrants (in either agricultural or non-agricultural jobs). ${ }^{c}$ is equal to $a-b$. Standard errors in parentheses (). Std. errors clustered at the household level. Significance level : * $p<0.10$, ** $p<0.05$, *** $p<0.01$. The controls of the regressions are the same as included in table 3 . 


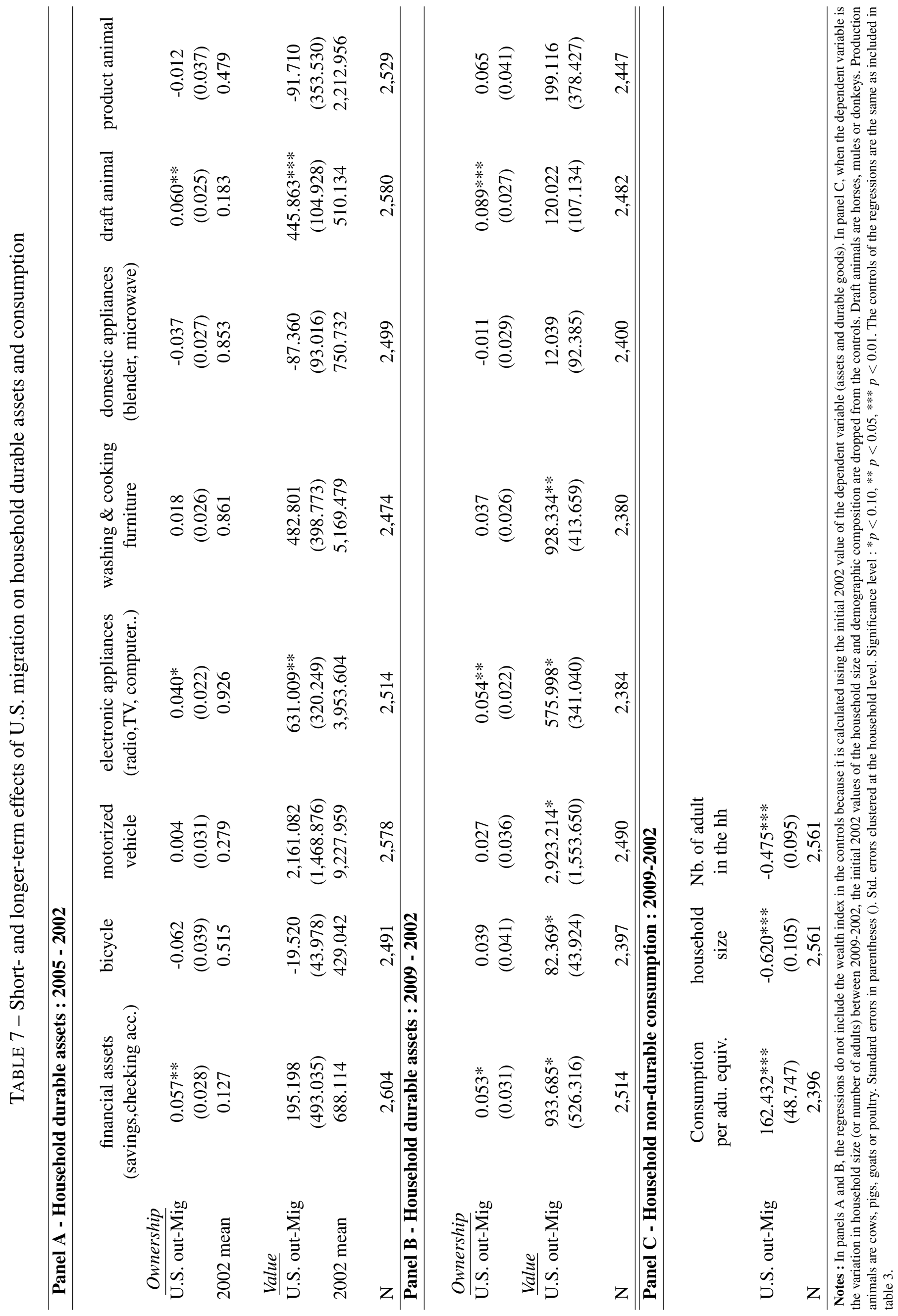




\section{Appendix}

FIGURE 2 - Pre-migration time trends in labor supply using ENOE data

Average differences between households with and without

U.S. migrants by quarters preceding migration

(a) Participation

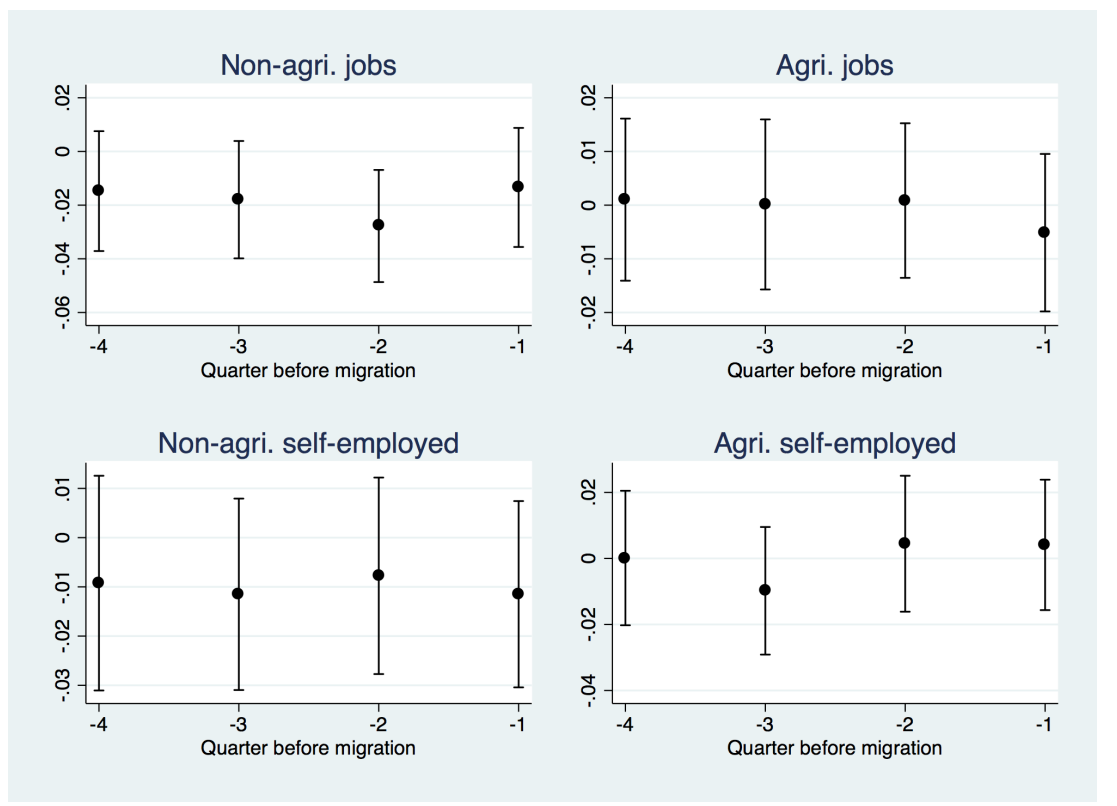

(b) Weekly hours

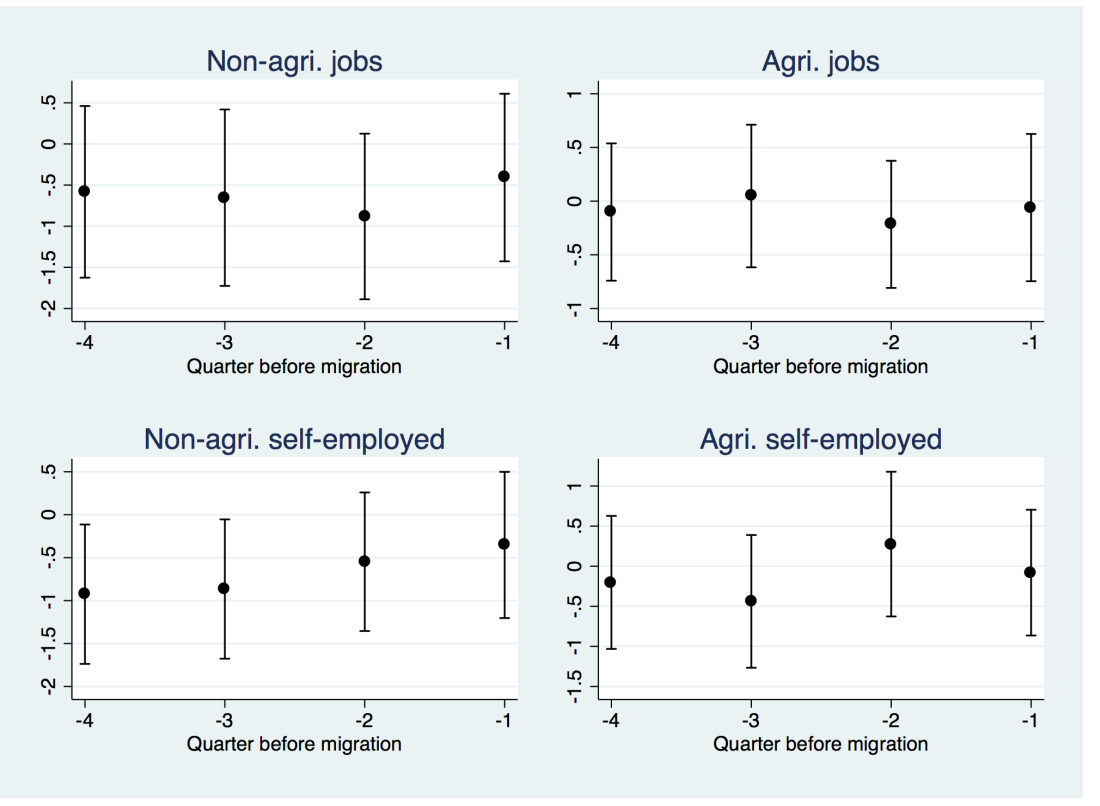

Notes : The data come from the rural sample of the ENOE survey in 2005, 2006 and 2007, interviewing the same households for five consecutive quarters. The sample is made of about 40,000 different households interviewed for five quarters, constituting a total of about 575,000 person-quarters observations. Every quarter, a little more than $1 \%$ of the households send a least one member to the U.S. The graph plots the $95 \%$ confidence interval and the point estimate $\widehat{\delta}_{k}$ of the difference in labor allocation between households with and without U.S. migrant against the number of quarters $k$ before migration, using the following regression :

$$
Y_{i h q}=\sum_{k=1}^{4} \delta_{k} \cdot M_{h q}^{k}+\eta_{p, q}+u_{i h q}
$$

with $Y_{i h q}$ the labor supply of individual $i$ in household $h$ at time $q$ and $M_{h q}^{k}$ a dummy equal 1 if, at time $q$, the household sends a migrant $k$ quarter later - which means between 0 and 3 months later if $k=1$ and between 9 and 12 months if $k=4$. The vector $\eta_{p, q}$ consists of municipality and time fixed effects. 


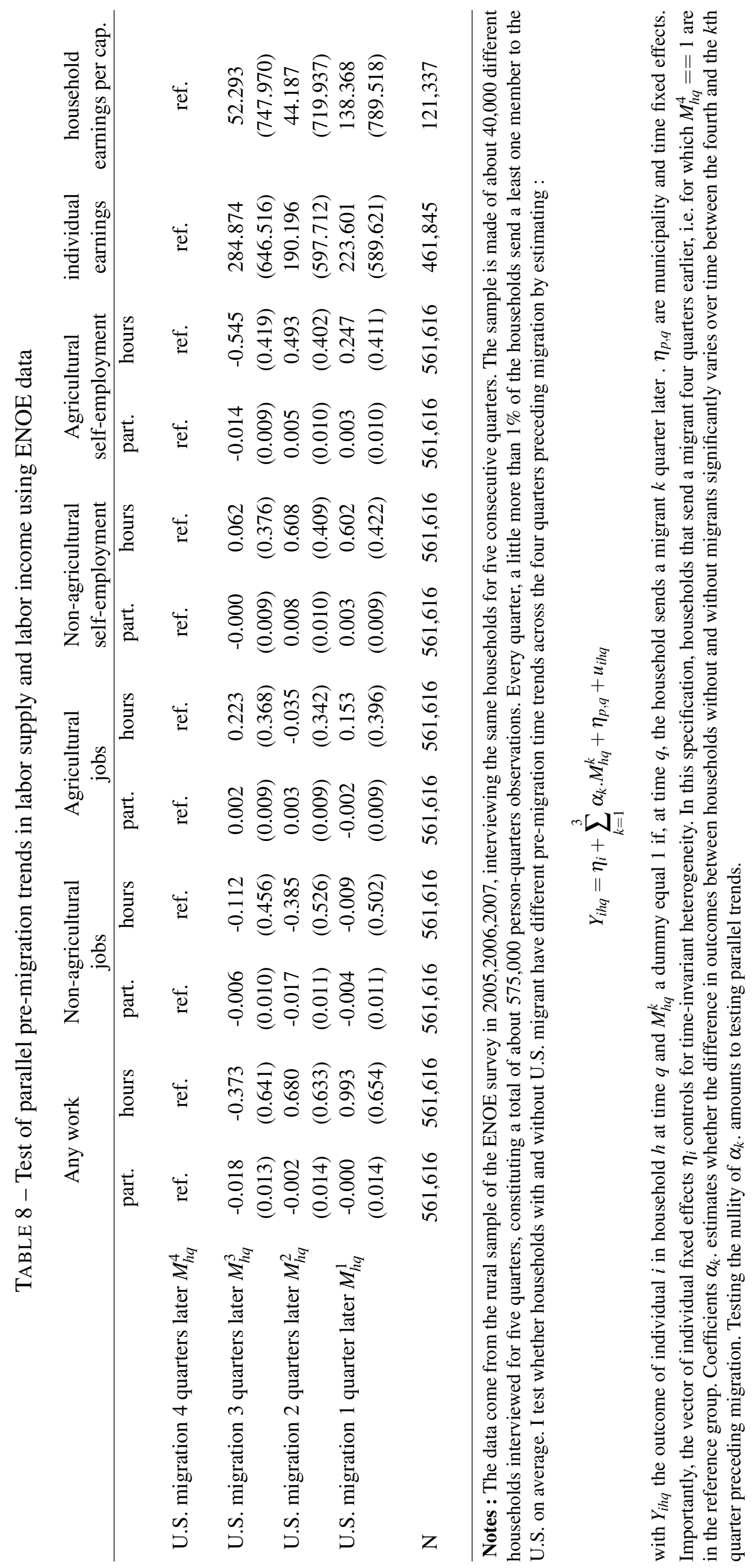


TABLE 9 - Time use of non-migrant individuals

\begin{tabular}{lccc}
\hline & Household chores & Care for children and elderly & School attendance \\
\hline U.S. out-Mig & 0.238 & 0.953 & -0.005 \\
& $(0.844)$ & $(0.959)$ & $(0.010)$ \\
N & 5,834 & 5,728 & 7,029 \\
2002 mean & 14.733 & 9.285 & 0.089 \\
\hline
\end{tabular}

Notes : Household chores include collecting water and firewood, cooking and preparing food, washing clothes and cleaning the house. Caring for children and elderly include time spent in taking care of elder, sick people, children and helping any home member to study or complete homework.

TABLE 10 - Initial households characteristics of rural sample in 2002

\begin{tabular}{lcc}
\hline \hline & mean & $\begin{array}{c}\text { standard } \\
\text { deviation }\end{array}$ \\
\hline hh out-migration to US (2002-2005) & 0.111 & $(0.314)$ \\
hh returned migration from U.S. (2002-2005) & 0.007 & $(0.085)$ \\
hh out-migration within Mexico (2002-2005) & 0.056 & $(0.229)$ \\
Ownership of financial assets & 0.124 & $(0.329)$ \\
Ownership of bicycle & 0.510 & $(0.500)$ \\
Ownership of motorized vehicle & 0.279 & $(0.449)$ \\
Ownership of electronic appliances (radio,TV, computer..) & 0.926 & $(0.262)$ \\
Ownership of washing or cooking furniture & 0.861 & $(0.347)$ \\
Ownership of domestic appliances (blender, microwave) & 0.853 & $(0.355)$ \\
Ownership of draft animal & 0.182 & $(0.386)$ \\
Ownership of production animal & 0.474 & $(0.499)$ \\
death hh member betw. 2002-2005 & 0.060 & $(0.237)$ \\
Illness hh member betw. 2002-2005 & 0.083 & $(0.276)$ \\
Job loss or Business failure betw. 2002-2005 & 0.036 & $(0.187)$ \\
Crop Loss betw. 2002-2005 & 0.049 & $(0.215)$ \\
House $\backslash$ business $\backslash$ animals loss betw. 2002-2005 & 0.029 & $(0.168)$ \\
death hh member betw. 1998-2002 & 0.023 & $(0.151)$ \\
Illness hh member betw. 1998-2002 & 0.102 & $(0.302)$ \\
Job loss or Business failure betw. 1998-2002 & 0.061 & $(0.239)$ \\
Crop Loss betw. 1998-2002 & 0.106 & $(0.308)$ \\
House $\backslash$ business $\backslash$ animals loss betw. 1998-2002 & 0.049 & $(0.215)$ \\
\hline Observations & 2642 & \\
\hline \hline
\end{tabular}

